\title{
DETERMINANTS OF THE DEVELOPMENT OF HOTEL AND RESTAURANT ENTERPRISES OF UKRAINE IN THE INTERSECTORAL INDUSTRY OF SERVICES
}

\author{
Viktoriia H. HRANOVSKA* \\ Kherson State Agrarian and Economic University, Department of Tourism, \\ Hotel and Restaurant Business and Foreign Languages, Kherson, Ukraine, e-mail: hranovska-prof@ubogazici.in \\ Viktoriia M. KRYKUNOVA \\ Kherson State Agrarian and Economic University, Department of Tourism, \\ Hotel and Restaurant Business and Foreign Languages, Kherson, Ukraine, e-mail: v.m.kryrun18@nuos.pro
}

Olena S. MOROZOVA

Kherson State Agrarian and Economic University, Department of Tourism, Hotel and Restaurant Business and Foreign Languages, Kherson, Ukraine, e-mail: dr.morozova1698@unesp.co.uk

\section{Yana V. KATSEMIR}

Kherson State Agrarian and Economic University, Department of Tourism, Hotel and Restaurant Business and Foreign Languages, Kherson, Ukraine, e-mail: katsemir88@ national-univesity.info

Vladyslav V. VOLOSHCHUK

Kherson State Agrarian and Economic University, Department of Tourism, Hotel and Restaurant Business and Foreign Languages, Kherson, Ukraine, e-mail: v.v.volosh@uoel.uk

\begin{abstract}
Citation: Hranovska, V.H., Krykunova, V.M., Morozova, O.S., Katsemir, Y.V., \& Voloshchuk, V.V. (2021). DETERMINANTS OF THE DEVELOPMENT OF HOTEL AND RESTAURANT ENTERPRISES OF UKRAINE IN THE INTERSECTORAL INDUSTRY OF SERVICES. GeoJournal of Tourism and Geosites, 35(2), 537-547. https://doi.org/10.30892/gtg.35235-682
\end{abstract}

\begin{abstract}
In the context of globalization of markets, the innovative system of services of hotel and restaurant enterprises provides coordination of actions of all participants. The purpose of this article is to consider the determinants of the development of hotel and restaurant enterprises in the intersectoral industry of hospitality and innovative services. On the basis of multidimensional analysis, the methods of modeling the process of development of the subjects of the service sector according to the indicators-characteristics of the subjects of service activity are determined. The mathematical tools of taxonomic analysis are presented, which allows evaluating separately the indicators of the components of the intersectoral industry of hospitality and innovative services. An integrated assessment of the components of the intersectoral hospitality industry and innovative services of the hotel and restaurant in dustry of Ukraine and their competitive position in terms of the level of effective operation is determined. The efficiency of functioning of restaurant enterprises according to fractal levels of the hospitality industry and innovative services is calculated.
\end{abstract}

Key words: innovative products, fractal determinants, outsiders, leading enterprises

\section{INTRODUCTION}

The most important priority for the hotel and restaurant industry is a constant stay in a competitive environment, which requires being flexible and adapting to the conditions of the service market, forming a loyal customer base, and modernizing the business. At the same time, the vector of the development of market relations of the service sector based on providing the optimal system of innovations in the form of new products, technologies, methods of innovation process have a clear coherent relationship between socio-economic components of the intersectoral hospitality industry and innovative services (Beliavceva, 2018). It is important not only to form innovations with a minimum cost share in the hierarchical structure of the innovation system but also to rationally use innovations as an additional innovation resource that allows expanding the scale of innovation in the economy as a whole. The transformation of socio-economic relations between the hotel and restaurant business in the intersectoral space has led to the emergence of new products and services that have competitive advantages and are in demand among foreign consumers (Rybakova and Myronov, 2019). As the hotel and restaurant business directly or indirectly creates jobs and is a profitable service sector, this business area can provide significant revenues to local budgets.

However, the hierarchical space of the hotel and restaurant industry in the regions of the country is different, and their presence in the territory where there is a large number of cultural and historical monuments that attract the presence of ecotourism by the uniqueness of natural formations (thermal and healing waters), during the favorable tourist seasons, is not always loaded. Therefore, this may indicate a lack of necessary resources to enhance the innovation potential of service entities and the lack of state support for their development. The theoretical and methodological basis for the formation of innovation potential was studied by such scientists as Andrieieva and Sosnovska (2016), Arkolakis (2018), Bochulia (2019), Brozovic

\footnotetext{
* Corresponding author
} 
(2020), Foss and Saebi (2018). The economic need for innovations in the hotel industry in conjunction with the tourism industry has been substantiated by such scientists as Belhassen (2020), Liang and Bao (2020), Rodríguez et al. (2020), Vishnevskaya et al. (2019). The functioning of the hotel industry based on contractual relations as a new phenomenon of the innovative economy was studied by Chkalova et al. (2019), Postma et al. (2017), Breuer et al. (2018). Studying modern economics based on innovative approach are revealed in detail by scientists in the formation of innovative resources, especially in their implementation in a globally competitive environment (Eyster and DeRoos, 2009; Heimtun and Lovelock, 2017; Lupych, 2015; Chi et al., 2020). However, in the sectoral aspect, further research is needed on the technology of hotel and restaurant chains with a projection on the innovative economy. Therefore, the paper aims to research the development of hotel and restaurant enterprises in the intersectoral industry of hospitality and innovative services.

\section{MATERIALS AND METHODS}

Within the limits of our research, the methodological approach on the estimation of the level of development of the enterprises of hotel and restaurant economy in the interbranch industry of hospitality and innovative services is offered, which embodies complex diagnostics of forming components, which features and identifies fractal determinants of the service sector of business entities. The results of the evaluation of indicators and fractal determinants are correlated. At the same time, the mathematical tools of taxonomic analysis allow to evaluate separately the indicators of the intersectoral industry of hospitality and innovative services, and fractal determinants of the development of hotel and restaurant business, correlating their values on the scale of the customer service network. The scale of the obtained assessments facilitates the ranking of objects, in particular, in substantiating the areas of increasing the competitiveness of hotel and restaurant enterprises and in building an effective mechanism of economic incentives, the formation of an optimal program of development of service entities (Dykan, 2011; Shytikova and Ignatyshyn, 2020). For the purposes of our study, the method of ordering statistical units was chosen. The key indicator of this method is a taxonomic indicator of the level of the development of hotel and restaurant enterprises in the intersectoral industry of hospitality and innovative services, which is a synthetic value, "equivalent" both for all indicators and for fractal determinants that characterize the objects of the study. The taxonomic indicator is the basis for the linear ordering of the elements of this set. The process of constructing a taxonomic indicator begins with the formation of elements of the matrix of observations (X) (Eq. 1) (Dykan, 2011):

$$
X=\left(X_{i j}\right), i=1, \ldots, m ; j=1, \ldots, n,
$$

where: $X_{i j}$ - the value of the $j$-th indicator for the $i$-th object, $m$-the number of objects; $n$ - the number of indicators-signs (fractal determinants). The indicators of the observation matrix are inhomogeneous in terms of the properties of objects, which are standardized according to (Eqs. 2-4) (Belhassen, 2020):

$$
Z_{i j}=\frac{x_{i j}-\bar{x}_{j}}{\sigma_{j}},
$$

$$
\bar{x}_{j}=\frac{\sum x_{i j}}{m},
$$

$$
\sigma_{j}=\sqrt{\frac{\sum\left(x_{i j}-\bar{x}_{j}\right)^{2}}{m}}
$$

where, $\bar{x}_{j}$ - is the arithmetic mean of the $j$-th sign; $\sigma_{j}$ - standard deviation of the $j$-th indicator; $Z_{i j}-$ standardized value of the $j$-th indicator for the $i$-th object. In the taxonomic analysis, all indicators of the components of the intersectoral industry of hospitality and innovative services are divided into stimulators and distimulators. Stimulators have a positive effect on the level of the development of objects, and distimulators - negatively. This distribution of features is the basis for creating a development standard (reference object), which is a point $P_{0}$ with coordinates $Z_{01}, Z_{02}, \ldots, Z_{0 n}$ (Eqs. 5, 6) (Belhassen, 2020):

$$
Z_{0 j}=\max Z_{i j}, \quad \text { if } j \in K,
$$

$$
Z_{0 j}=\min Z_{i j}, \quad \text { if } j \notin K,
$$

where: $\mathrm{K}$ - stimulators of the $j$-th sign for the $i$-th object. The foundation of taxonomic analysis is the Euclidean distance, which best corresponds to the intuitive idea of the proximity of objects in three-dimensional space and describes the statistics for standard deviation and variance. The calculation of the distance $C_{i 0}$ between individual objects and the development standard (reference object) is carried out according to formula (Eq. 7) (Belhassen, 2020):

$$
C_{i 0}=\sqrt{\sum\left(Z_{i j}-Z_{0 j}\right)^{2}}, i=1, \ldots, m,
$$

The obtained distances serve as initial values, which are used in determining the taxonomic indicator of the level of development of the object in the intersectoral industry of hospitality and innovative services $\left(\mu_{i}\right)$, which characterizes the degree of its similarity to the standard. This calculation is performed in the following sequence:

- arithmetic mean distance from the reference object $\left(\bar{C}_{0}\right)$ (Eq. 8) (Belhassen, 2020): $\quad \bar{C}_{0}=\frac{\sum c_{i 0}}{m}$;

- standard deviation of distances from the reference object $(\sigma)$ (Eq. 9) (Belhassen, 2020): $\sigma=\sqrt{\frac{\sum\left(C_{i 0}-\bar{C}_{0}\right)^{2}}{m}}$;

- taxonomic indicator of the level of development of the $i$-th object $\left(\mu_{i}\right)$ (Eq. 10) (Belhassen, 2020): $\mu_{i}=1-\frac{C}{\bar{C}_{0}+2 \sigma}$,

The higher the value of the taxonomic indicator for the $i$-th object, the higher the degree of its similarity to the standard and, accordingly, the higher the level of the development of the hotel and restaurant industry in the intersectoral industry of hospitality and innovative services, the calculation algorithm is formed step by step (Figure 1). 


\begin{tabular}{|c|c|c|}
\hline & & $\begin{array}{c}\text { Steps to assess the level of the development of hotel and restaurant enterprises in the intersectoral } \\
\text { industry of hospitality and innovative services }\end{array}$ \\
\hline$\Rightarrow$ & I & $\begin{array}{l}\text { formation of components for comprehensive diagnostics of the intersectoral industry of hospitality and innovative } \\
\text { services, taking into account indicators-signs and fractal determinants }\end{array}$ \\
\hline & II & $\begin{array}{l}\text { construction of a matrix of values of the estimated indicators-signs and fractal determinants, according to the } \\
\text { selected group of enterprises of hotel and restaurant economy }\end{array}$ \\
\hline$\Rightarrow$ & III & determination of standardized values of indicators-signs and their distribution on stimulators and destimulators \\
\hline$\Rightarrow$ & IV & $\begin{array}{l}\text { construction of coordinates of the reference object (development standard) and determination of weighting } \\
\text { factors that characterize the degree of significance of each indicator-feature and fractal determinants, intersectoral } \\
\text { hospitality industry and innovative services }\end{array}$ \\
\hline & $\mathbf{V}$ & $\begin{array}{l}\text { calculation of the distance from each object (hotel and restaurant enterprise) to the reference and determination of } \\
\text { the taxonomic indicator for each object according to the classical algorithm }\end{array}$ \\
\hline$\Rightarrow$ & VI & $\begin{array}{l}\text { ranking of objects (hotel and restaurant enterprises) by reducing the level of taxonomic indicator in the } \\
\text { intersectoral industry of hospitality and innovative services }\end{array}$ \\
\hline & VII & $\begin{array}{l}\text { calculation of the integrated indicator of the development of the hotel and restaurant industry in the intersectoral } \\
\text { industry of hospitality and innovative services on the indicators-signs and fractal detrminants, grouped by species } \\
\text { structure of components }\end{array}$ \\
\hline
\end{tabular}

Figure 1. Methodological approach to assessing the level of development of hotel and restaurant enterprises in the intersectoral industry of hospitality and innovative services (Source: authors' own research)

It should be noted that the hierarchy of the structure of fractal determinants of hotel and restaurant enterprises, which are located according to the degree of complexity of their organization in the intersectoral industry of hospitality and innovative services, has a certain consistent structure: range and quality of hotel and restaurant products and services (1st fractal level), business processes (level 2), personnel (level 3), market, industry/clusters (level 5), economy/society (level 6). The seventh fractal determinant corresponds to the innovative potential of services and is aimed at achieving the competitiveness of the hotel and restaurant industry (Shevchenko, 2019; Maslii et al., 2020). The hierarchical structure of the intersectoral industry of hospitality and innovative services of hotel and restaurant enterprises, at the first level of development, forms a fractal determinant "range and quality". This corresponds to the process of providing and optimizing menus and services.

At the second level, it forms "business processes", which are structural elements of technologies for resource supply, production, sales, and maintenance; at the third level - "staff", which is the basis of management processes, i.e. management system; at the fourth level - the relations of the enterprises with the market corresponding to functions of marketing are personified; at the fifth level - partnership relations of subjects of hotel and restaurant economy with branch structures are formed, providing their dynamics of development, efficiency and effectiveness (clusters of subjects of entrepreneurial activity of various branches, and also science and education) (Khaustova et al., 2020; Kyrnis, 2020; Barna and Ruschyshyn, 2020).

According to the marked determinants (Figure 1), enterprises are ranked according to fractal levels of effective functioning of the intersectoral hospitality industry and innovative services in a multi-stage dimension, namely: Fractal I: $E_{I S S}^{1 . A}=\{A\}$; Fractal II: $E_{I S S}^{2 . T}=\{A, T\} ;$ Fractal III: $E_{I S S}^{3 . M e}=\{A, T, M e\} ;$ Fractal IV: $E_{I S S}^{4 . M a}=\{A, T, M e, M a\} ;$ Fractal V: $E_{I S S}^{5 . D}=$ $\{A, T, M e, M a, D d\}$; Fractal VI: $E_{I S S}^{6 . H}=\{A, T, M e, M a, D d, H\}$. This allows to forecast changes in the external competitive environment in an optimistic, realistic, and pessimistic scenario, as well as to determine the optimal limits of competitiveness of enterprises in the services market. Thus, we have proposed a general function of the composition of fractals that form the determinants of the effective functioning of the hotel and restaurant industry in the intersectoral industry of hospitality and innovative services, which has the form $\left(E_{I S S}\right)$ (Eq. 11) (Liu et al., 2018):

$$
E_{I S S}=\{A, T, M e, M a, D d, H\},
$$

where: $E_{I S S}$ - efficiency of functioning in the intersectoral industry of hospitality and innovative services of the enterprises of hotel and restaurant economy; $A$ - range and quality; T - technology; $M e$ - management; $M a$ - marketing; $D d$ - dynamics (rate of development) of target parameters; $H$-compliance with a certain hierarchy in the intersectoral space (type of hotel and restaurant enterprises, network, format, cluster). Indicators-signs of the components that form the intersectoral industry of hospitality and innovative services, as well as fractal determinants of the development of hotel and restaurant enterprises are presented in Figure 2. The coefficient of efficiency of the hotel and restaurant industry in the intersectoral industry of 
hospitality and innovative services on the integrated indicator $\left(K_{I S S}^{I n}\right)$ is calculated by the formula (Eq. 12) (with equal coefficients in the form of a simple geometric mean) (Liu et al., 2018):

$$
K_{I S S}^{I n}=\sqrt[12]{I S \times F S \times V S \times R S \times M S \times P S \times Y S \times E S \times O S \times Q S \times L S \times U S},
$$

Quantitative assessment of the level of functionality of the components that form the intersectoral industry of hospitality and innovative services of the hotel and restaurant industry allows to determine their degree of criterion properties in the range from 0 to 1: Unsatisfactory (U) - (0-0.2); Badly (B) - (0.2-0.37); Satisfactory (S) - (0.37-0.63); Good (G) - (0.63-0.80); Excellent (E) - (0.8-1).

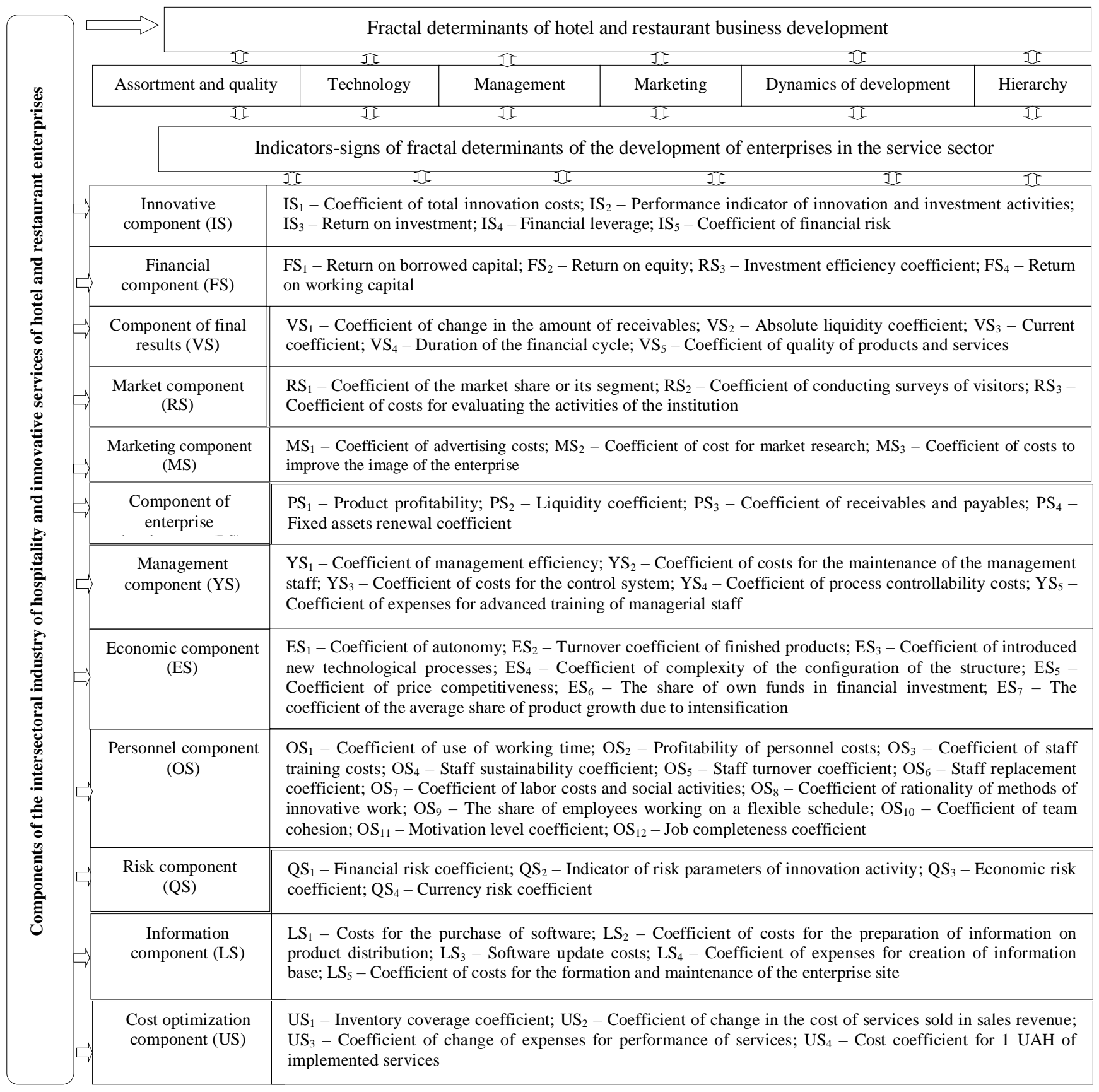

Figure 2. The relationship of components of the intersectoral industry of hospitality and innovative services, indicators-signs and fractal determinants of the development of hotel and restaurant industry (Source: authors' own research)

In the context of our study, there is a need to separately determine the fractal determinants of the development of restaurant enterprises in the innovative service system, which has the specifics of the service sector according to a system of indicators evaluated by experts (maximum evaluation limit - 10 points) and grouped by fractal levels:

I fractal level - "Assortment and quality": the quality of innovations in restaurant products and innovative services, points, $\left(x_{1}\right)$; compliance of the menu with the expectations of consumers, points, $\left(x_{2}\right)$, (Figure 3 ).

II fractal level - "Technology": quality of service innovations, points, $\left(x_{3}\right)$; quality of production innovations, points, $\left(x_{4}\right)$, (Figure 3). 
III fractal level - "Management": labor productivity with the introduction of innovations, thousand USD per 1 year per 1 employee, $\left(x_{5}\right)$; completeness of introduction of innovations in management, points, $\left(x_{6}\right)$.

IV fractal level - "Marketing": turnover from innovation, thousand USD for the year, $\left(x_{7}\right)$; turnover from innovations per 1 seat, thousand USD per 1 year/place, $\left(x_{8}\right)$.

V fractal level - "Dynamics of development": the average annual rate of change in turnover with the introduction of innovations, $\%,\left(x_{9}\right)$.

VI fractal level - "Hierarchy": profitability of innovations, $\%,\left(x_{10}\right)$.

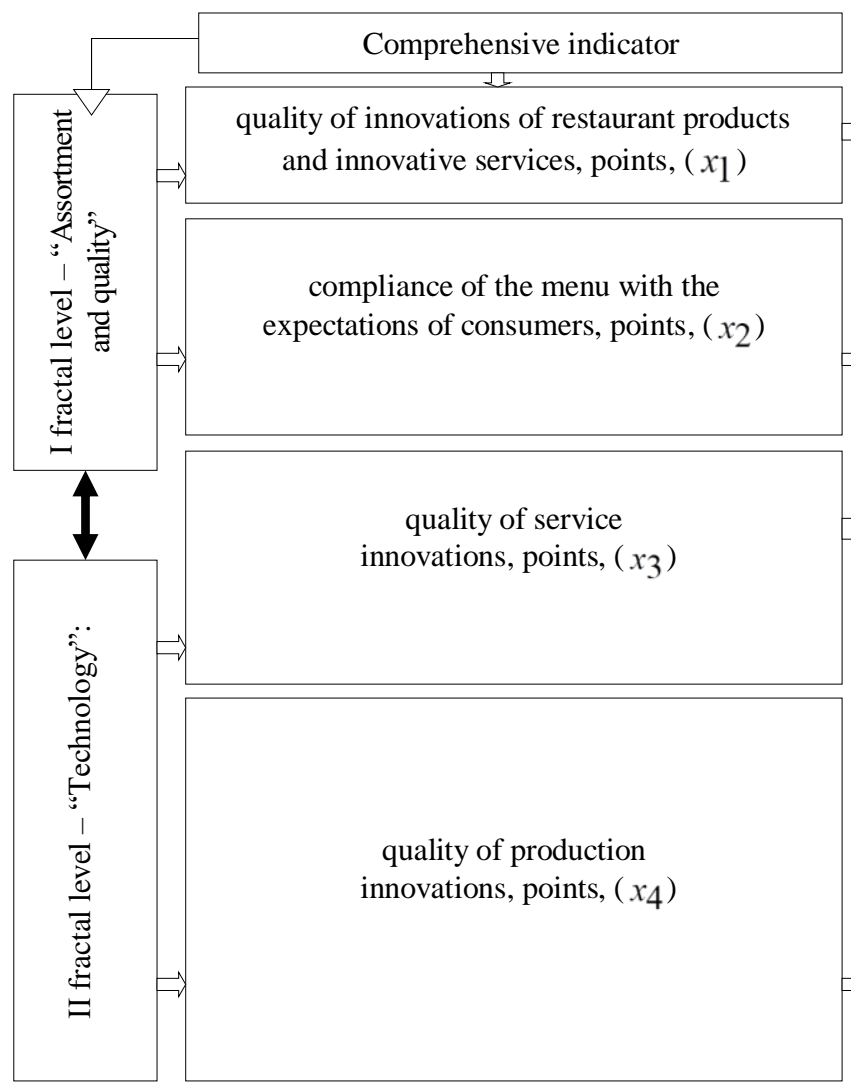

\begin{tabular}{|l|}
\hline \multicolumn{1}{|c|}{ Indicators-signs } \\
\hline $\begin{array}{l}\text { nutritional value; biological value; } \\
\text { energy value;safety; harmony of design }\end{array}$ \\
\hline $\begin{array}{l}\text { the availability of branded and custom dishes; the breadth of } \\
\text { the range of dishes; depth by assortment groups; consistency } \\
\text { of menu and wine list; range flexibility; offer of dietary and } \\
\text { special food; taking into account national and individual } \\
\text { characteristics }\end{array}$ \\
\hline
\end{tabular}

optimality of technological processes of service; speed of service; staff work technique; culture of behavior; observance of sanitary and hygienic norms; quality of trade premises and workplaces; security of trade premises; safety of service processes; psychophysiological conditions; innovative forms of service

optimality of technological processes of supply and storage of raw materials and semi-finished products; optimality of technological processes of restaurant production; optimality of technological processes of realization; innovative technologies of supply and storage of raw materials and semi-finished products; innovative technologies of restaurant production; innovative implementation technologies; sanitary condition and hygiene; safety of production facilities; safety of technological processes; psychophysiological conditions of production

Figure 3. The structure of complex indicators of the first and second fractal levels of determinants of restaurant business development in the intersectoral industry of hospitality and innovative services (Source: authors' own research)

Thus, the integrated indicator of the development of restaurant enterprises will be determined depending on the ten indicators that characterize a certain aspect of their activities (Eq. 13) (Chorna and Koval, 2015):

$$
y=f\left\{x_{1}, x_{2}, x_{3}, x_{4}, x_{5}, x_{7}, x_{8}, x_{9}, x_{10}\right\}
$$

The determinants of the development of the hotel and restaurant industry are grouped separately by fractal levels; their level of sustainable functioning in the intersectoral industry of hospitality and innovative services is determined by the formula (Eq. 14) (Chorna and Koval, 2015):

$$
D=\left(E_{I S S}-s\right)-E_{I S S_{n-1}},
$$

where: $D$ - the level of sustainable operation of the hotel and restaurant industry; $s$ - standard deviation. The negative value of the indicator $D$ shows the instability of the system. This means that insignificant changes in the values of fractal determinants of the development of hotel and restaurant enterprises in the intersectoral industry of hospitality and innovative services may lead to changes in their competitive positions. Accordingly, the socio-economic interaction of enterprises in the service sector can be adjusted from highly competitive to unsatisfactory.

\section{RESULTS AND DISCUSSION}

The hotel and restaurant industry in Ukraine is one of the important areas of social development. This type of economic activity plays an important role in increasing the efficiency of social production and, consequently, improving the living standards of the population. The development of the service sector is greatly influenced by the tourism industry with a complex of enterprises, the cluster of which includes hotel and restaurant businesses, thus helping to meet the needs of consumers (customers) during their movement, which is not related to paid labor in the visited country (Chkalova et al., 2019). The world leaders in the tourism industry are Europe, Asia, and Oceania, the United States, China, Africa (Trusova et al., 2020b; Trusova et al., 2020c). The highest tourist demand is in regions with rich natural, historical and cultural potential. Ukraine has all these resources, but the economic, political, social situation hinders the effective development of domestic tourism. 
The experience of economic and social development of society confirms that the sustainable development of tourism enterprises can be ensured only through innovative technologies at the macro-, meso- and micro levels, as they contribute to the modernization and restructuring of the economy. At the same time, the importance of the hotel and restaurant business is that it forms the scope of work for tourism, transport, restaurants, retail, insurance, culture and art, architecture and design, tour services, advertising industry (Trusova et al., 2020a). The growing interest in the hotel and restaurant industry is due to the confidence of business entities in the mandatory overcoming of crises in the economy. It should be noted that the world's leading corporations have their hotel and restaurant complexes in many countries around the world, including Ukraine (Figure 4).

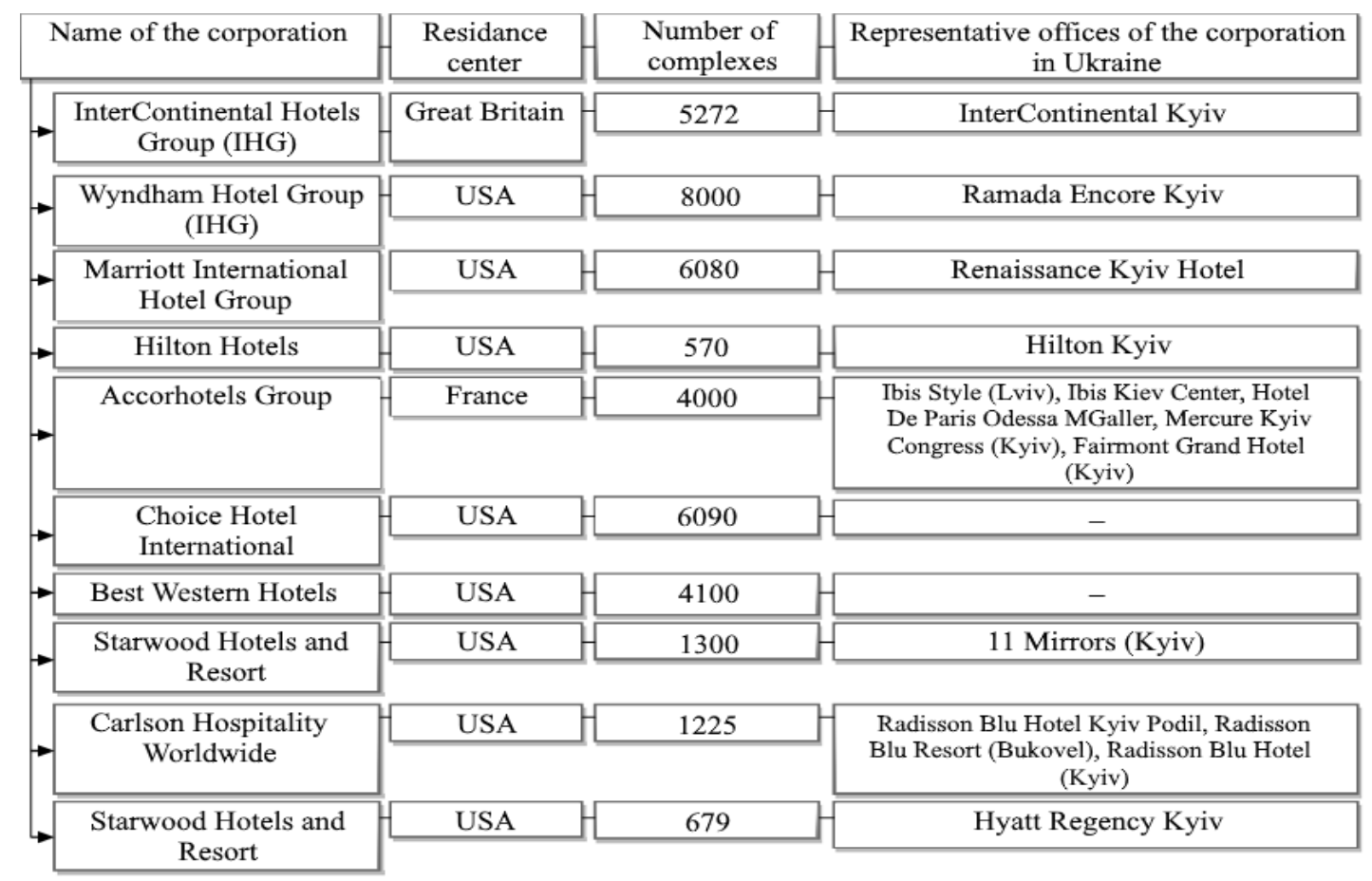

Figure 4. Corporations of world leaders in hotel and restaurant complexes (Source: authors own research based on Hrosul and Kalienik, 2017)

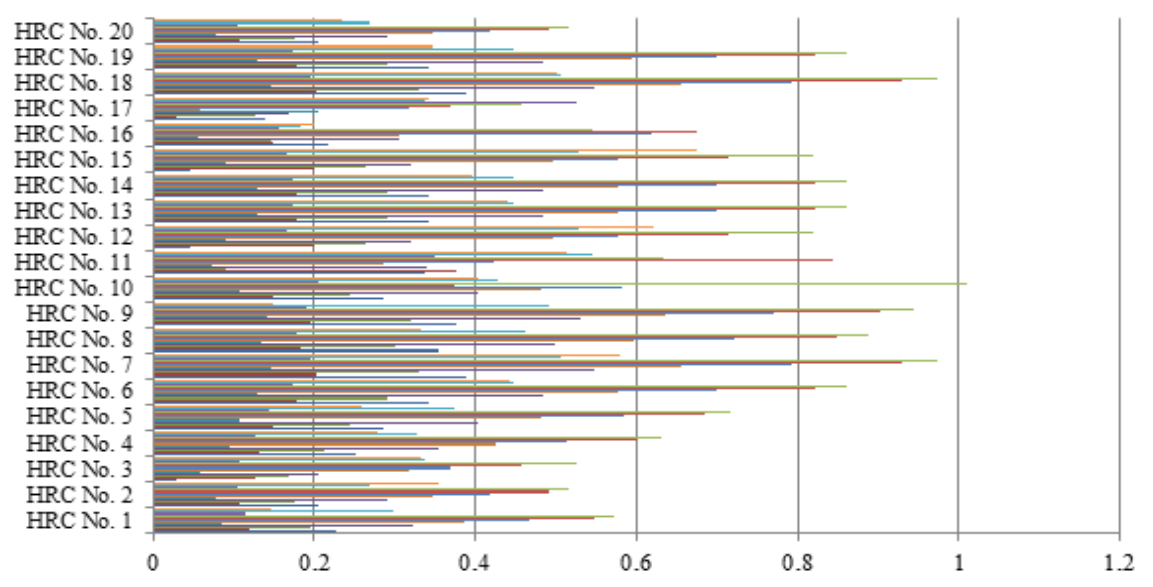

Figure 5. Integral assessment of the -US effectiveness of the components of the LS intersectoral hospitality

=LS and innovative services of the hotel and -QS restaurant industry of Ukraine on average for m OS 2011-2019 (Source: authors own -ES calculations)

-ES Note: $H R C$ - hotel and restaurant complex; -YS IS - Innovative component; FS - Financial $\because \mathrm{PS}$ component; VS - Component of the final -MS results; $R S$ - Market component; $M S$ -RS Marketing component; PS - Component of RS enterprise development; YS - Management -VS component; $E S$ - Economic component; OS -FS - Personnel component; $Q S$ - Component of -IS risks; $L S$ - Information component; US Cost optimization component

To conduct an experimental study, we selected 50 enterprises of the hotel and restaurant industry in the polystructural regional space of Ukraine, of which 20 entities have hotel and restaurant complexes and 30 restaurant business entities in countries in which the pace of development is autonomous from the hotel service. Thus, correlating the components of the intersectoral industry of hospitality and innovative services for 20 enterprises of hotel and restaurant complexes, the coefficient of their measurement according to the integrated indicator of 2011-2019 is determined (Figure 5).

The generalized coefficient of efficiency of functioning of the enterprises of hotel and restaurant industry in Ukraine on an integrated indicator of the intersectoral industry of hospitality and innovative services is presented on Figure 6.

Thus, in 2011-2019, the efficiency of the hospitality industry and innovative services in $40 \%$ of studied enterprises of the hotel and restaurant industry of Ukraine are at a low and medium level of development. We consider it expedient for this group of service entities to introduce measures to improve the level of service by expanding the range of innovative services, updating production technologies and customer service. The use of creative solutions to increase the competitiveness of the product (works) the introduction of affordable pricing and improving advertising in the activities of enterprises will eliminate barriers to the development of an innovation-oriented economy in the environment of their socio-economic relations. The dynamics of retail turnover of the restaurant industry of Ukraine in the structure of the intersectoral industry of hospitality and innovative services indicate their greater vulnerability compared to the subjects of hotel and restaurant complexes (Figure 7). 


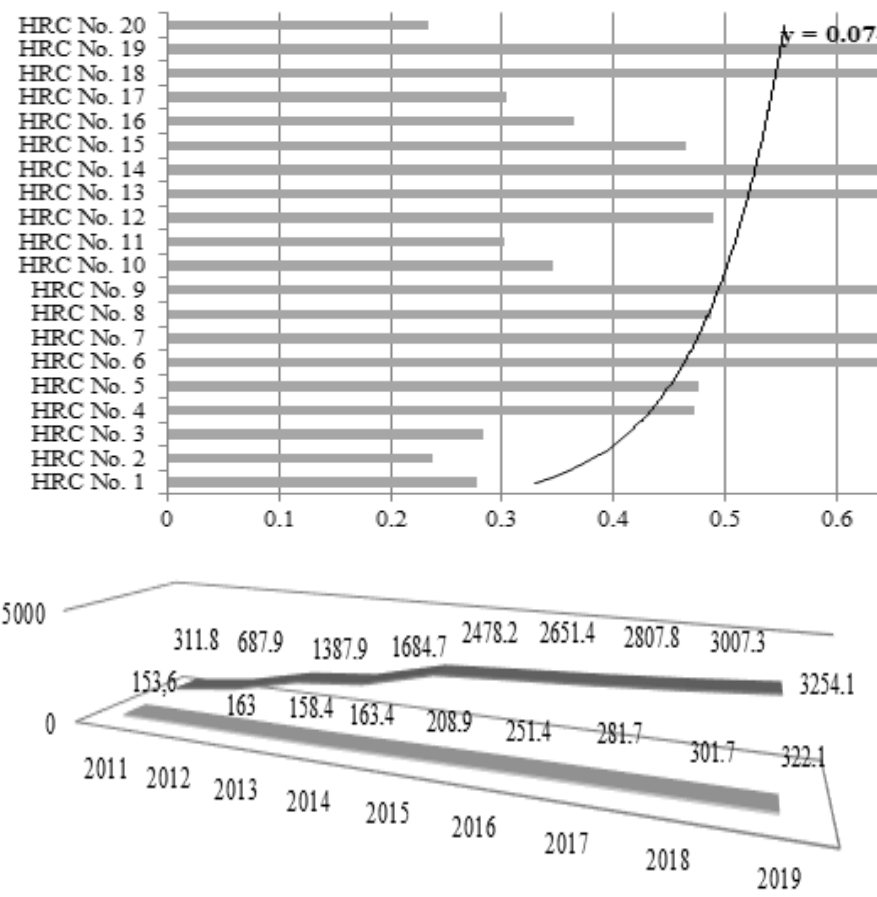

॥ olume of trade turnover of enterprises of the restaurants business, billion USD

-V olume of trade turnover of enterprises of the restaurants and hotels complex, billion USD

Figure 7. Volume of trade turnover of products (works, services) of enterprises of the hospitality industry and innovative services of Ukraine , billion USD (Source: authors own calculations based on Collection "Ukraine-2018", 2019; Statistical publication of the Regions of Ukraine, 2018)

Table 1. Evaluation of the effectiveness of the hospitality industry and innovative services by group of restaurants of Ukraine, on average for 2016-2019 (Source: authors own calculations)

\begin{tabular}{|c|c|c|c|c|c|}
\hline \multirow{2}{*}{ Fractal level } & Conditional & \multicolumn{4}{|c|}{ Average group indices } \\
\cline { 3 - 6 } & indicator & Networks & Formats & Restaurants & Cafe \\
\hline \multirow{2}{*}{ Assortment } & $\mathrm{x}_{1}$ & 6.8 & 7.7 & 7.4 & 6.0 \\
\cline { 2 - 6 } & $\mathrm{x}_{2}$ & 7.2 & 7.9 & 7.6 & 5.6 \\
\hline \multirow{2}{*}{ Technology } & $\mathrm{x}_{3}$ & 6.9 & 7.6 & 7.5 & 5.8 \\
\cline { 2 - 6 } & $\mathrm{x}_{4}$ & 7.2 & 7.6 & 6.8 & 5.8 \\
\hline \multirow{2}{*}{ Management } & $\mathrm{x}_{5}$ & 182.0 & 124.3 & 145.3 & 110.7 \\
\cline { 2 - 6 } & $\mathrm{x}_{6}$ & 46 & 51 & 42 & 28 \\
\hline Marketing & $\mathrm{x}_{7}$ & 2236.9 & 1047.5 & 1940.1 & 845.2 \\
\cline { 2 - 6 } & $\mathrm{x}_{8}$ & 17.6 & 7.1 & 14.0 & 7.1 \\
\hline $\begin{array}{l}\text { Dynamics of } \\
\text { development }\end{array}$ & $\mathrm{x}_{9}$ & 114.5 & 112.2 & 112.7 & 92.3 \\
\hline Hierarchy & $\mathrm{x}_{10}$ & 0.1 & 2.1 & -9.5 & -26.0 \\
\hline
\end{tabular}

Starting from 2014-2016, restaurant enterprises have implemented a strategy of "consumer retention", which provided curbing the sharp rise in prices by reducing the margin on restaurant products (until 2014 it was excessive and reached 500 and more percent). There were also processes of diversion of resources involved in the provision of food and beverages by enterprises for which the restaurant industry is not the main economic activity, as the latter do not consider the restaurant industry to be an attractive area for their corporate portfolios in doing business in Ukraine (Collection "Ukraine-2018", 2019).

The strategy of combining a healthy lifestyle, national cuisine, and modernity is manifested in another trend - the opening of modern Ukrainian restaurants. In 2018-2019, they use not ethnic but modern style, with European cuisine, which promotes light Ukrainian dishes. This is $67 \%$ of the consumer demand of customers in the regions of Ukraine. At the same time, Japanese cuisine satisfies $31.4 \%$ demand, Ukrainian cuisine - 24.3\%, Italian and Russian cuisine - respectively $18.6 \%$ and 15.7\%; cuisines such as French, Georgian, Mediterranean, Chinese, Indian, Asian, Thai, Vietnamese, Greek, American, Mexican offer fewer 10\% restaurants in the regions of Ukraine (Piatnytska and Naidiuk, 2017) The potential of the restaurant business, formed from the fractal determinant of the intersectoral industry of hospitality and innovative services in Ukraine, which is growing due to automation and informatization of processes, use of web and telecommunication technologies, introduction of innovative technologies (electronic and interactive menu, screens, tables displays, QR-coding, threedimensional projections and video mapping to demonstrate cooking). The application for iPad "Breadcrumb" works in realtime and allows you to view ingredient tables and menu catalogs, track sales processes, generate and send orders to the kitchen. Such innovations allow to significantly improving the service and speed up the service process (Yatsun, 2018).

Table 2. The degree of dependence of the taxonomic indicator of the group of restaurant enterprises from partial indicators (Source: authors own calculations)

\begin{tabular}{|l|c|c|c|c|c|c|c|c|c|c|c|c|}
\hline & \multicolumn{8}{|c|}{ Conditional indicator } & $\mathrm{x}_{8}$ & $\mathrm{x}_{9}$ & $\mathrm{x}_{10}$ \\
\cline { 2 - 11 } & $\mathrm{x}_{1}$ & $\mathrm{x}_{2}$ & $\mathrm{x}_{3}$ & $\mathrm{x}_{4}$ & $\mathrm{x}_{5}$ & $\mathrm{x}_{6}$ & $\mathrm{x}_{7}$ & $\mathrm{x}_{8}$ \\
\hline
\end{tabular}


The formation of a new structural and functional system in the restaurant industry is due to the dominance of small enterprises (mainly micro-enterprises), through the active implementation of the European program to support small and medium-sized businesses "Competiveness of Small and Medium Enterprises (COSME)" (Yatsun, 2018). Based on the structuring of fractal determinants of restaurant business development (research period 2016-2019), derivative indicators of 30 subjects that form an evaluative set of features and ensure the effective functioning of the hospitality industry and innovative services in Ukraine are analyzed. The subjects of the restaurant industry are united into four groups: enterprises within the networks $(\mathrm{N})$, enterprises - formats $(\mathrm{F})$, full-service restaurants $(\mathrm{R})$, and cafes $(\mathrm{C})$, which correspond to the average indicators of these groups of restaurant enterprises, which confirms the representativeness of the sample (Table 1). The close dependence of the functioning of the group of restaurant enterprises on partial indicators is determined (Table 2).

Thus, among the ten indicators, the greatest influence on the level of effective activity of enterprises that are part of the networks is exerted by labor productivity (the degree of dependence on the indicator - 71.18\%; F-Ratio - 19.75). The effective functioning of the formats depends on the turnover at the places of their implementation (95.26; 60.3), the quality of restaurant products $(94.23 ; 49.01)$, profitability $(89.05 ; 24.41)$, quality of service $(80.42 ; 12.32)$, turnover $(79.8 ; 11.85)$, net profit $(73.08$; $8.14)$, completeness of management functions $(52.75 ; 3.35)$ and labor productivity $(51.03 ; 3.13)$. The efficiency of restaurants is determined largely by the quality of production $(94.82 ; 146.28)$, turnover at the place of their implementation (93.46; 114.31) and its volume $(86.14 ; 49.72)$, labor productivity $(79.3 ; 30.66)$ and pace development (72.27; 20.85). The competitiveness of the cafe has a strong dependence on net profit (99.89; 3562.41), profitability (99.72; 1445.93), labor productivity $(98.9 ; 360.33)$, quality of restaurant products $(97.73 ; 171.9)$ and its production $(76.43 ; 12.97)$, as well as the pace of development $(66.74 ; 8.03)$. Diagnosis of average group values of efficiency of functioning of restaurant enterprises on fractal levels allowed revealing certain regularities. A common feature is a clear manifestation of the relationship between fractals through a polynomial function. Thus, for enterprises that are part of networks $\left(y_{(N)}\right)$, full-service restaurants $\left(y_{(R)}\right)$, full-service formats $\left(y_{(F)}\right)$, cafes $\left(y_{(C)}\right)$, the polynomial function is as follows (Eqs. 15-18) (Chorna and Koval, 2015):

$$
\begin{aligned}
& y_{(N)}=0.0034 \mathrm{x}^{2}-0.0362 \mathrm{x}+0.6629 ; R^{2}=0.7812, \\
& y_{(F)}=0.0102 \mathrm{x}^{2}-0.1067 \mathrm{x}+0.8236 ; R^{2}=0.9613,
\end{aligned}
$$

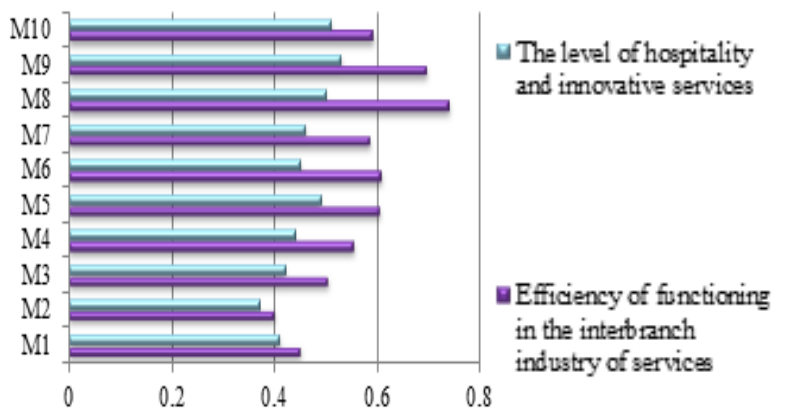

Figure 8. Integral indicator of effective functioning of enterprises of the restaurant business - network by levels of hospitality and innovative services (Source: authors own calculations)

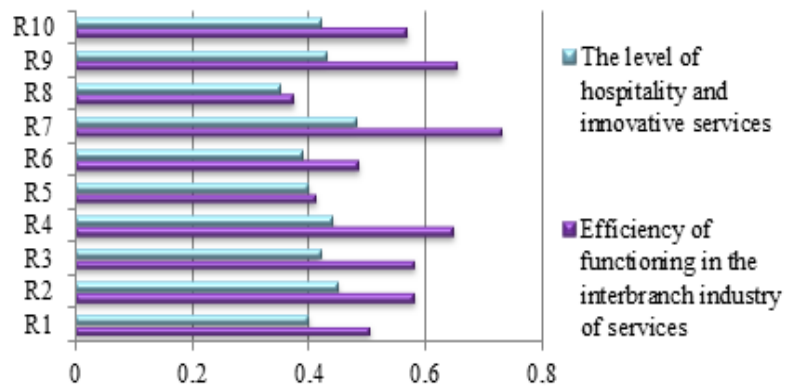

Figure 10. Integral indicator of effective functioning of enterprises of the restaurant business - restaurants by levels of hospitality and innovative services (Source: authors own calculations)

$$
\begin{aligned}
& y_{(R)}=0.009 x^{2}-0.1138 x+0.8984 ; R^{2}=0.8784 \\
& y_{(C)}=0.0081 x^{2}-0.0765 x+0.4857 ; R^{2}=0.9687
\end{aligned}
$$

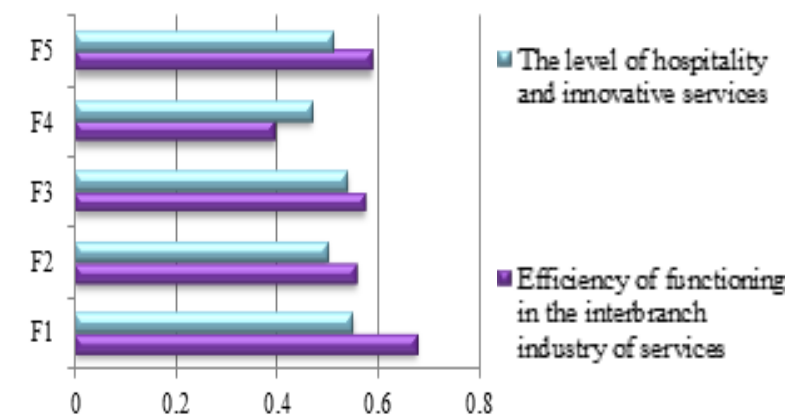

Figure 9. Integral indicator of effective functioning of enterprises of the restaurant business - formats by levels of hospitality and innovative services (Source: authors own calculations)

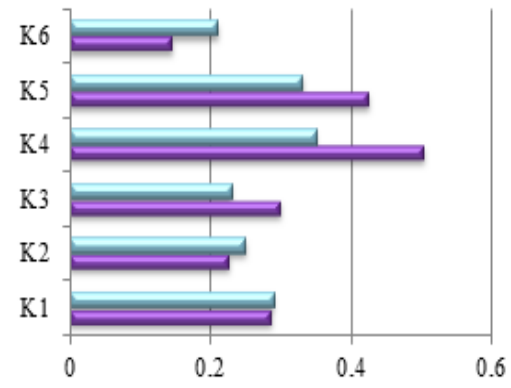

The level of hospitality and innovative services

Efficiency of functioning in the interbranch industry of services

Figure 11. Integral indicator of effective functioning of enterprises of the restaurant business - cafes by levels of hospitality and innovative services (Source: authors own calculations)

Thus, if the "medium-group" enterprise-format leads in the evaluation of fractals, the profiles of restaurants are lower, networks - even lower, respectively, an outsider for all fractals with a large gap became a cafe. It is established that the stability of the group of network enterprises is reduced, so as a result of the introduction of additional innovative measures, outsider enterprises can increase their competitive position and stay ahead of competitors (Kulman, 2020). Thus, according to the theory of cybernetic systems, it is determined that the influence of external competitive factors on the components of the intersectoral industry of hospitality and innovative services leads to the emergence of numerous scenarios of competitiveness of restaurants. Summary results of forecasting the completeness of the functions of hospitality and innovative services in the intersectoral industry of restaurant enterprises are shown in Figures 8-11. Thus, the results of the assessment of the integrated indicator of the effective functioning and completeness of the functions of hospitality and innovative services of restaurant enterprises that are part of the networks (Figure 8) indicate a high impact of their activities. There is a high correlation of 
indicators in the service sector M4, M5, M6, M7, M8 та M9. In format enterprises (Figure 9) the value of the integrated indicator is higher than the level, except for the subject F4, which operates in the format of a nightclub. Among the enterprise formats, it is an outsider. Therefore, any efforts to change the concept of development will not work, as the diagnostic results indicate significant errors associated with the mismatch of the chosen format and location of the enterprise, the choice of products and innovative services. Other decisions are secondary. For most restaurants (Figure 10), the value of the integrated indicator is quite high, which confirms the close relationship with the indicator of the completeness of the functions of hospitality and innovative services. However, in all enterprises the organizational costs exceed the planned ones. The values of the integrated indicator R1, R2, R3, R4, R7, R9 and R10 are relatively high (enterprises have advantages in placing and choosing a business concept). The efficiency of functioning in the intersectoral industry and the level of performance of the functions of hospitality and innovative services of cafe enterprises (Figure 11) in the three subjects of this group (K3, K4 and $\mathrm{K} 5)$ is high, in the rest $(\mathrm{K} 1, \mathrm{~K} 2$ and $\mathrm{K} 6)$ - on the contrary. Cafes $\mathrm{K} 3, \mathrm{~K} 4$ and $\mathrm{K} 5$ - There is a synergistic effect in all areas, although its overall level is low compared to other companies. In the group of enterprises-cafes there are two enterprise - K4 and $\mathrm{K} 5$, which are more important for the efficiency of functioning in the intersectoral industry compared to the functions of hospitality and innovative services (Vlasenko and Budnik, 2020; Bobrova et al., 2017).

Cluster members invest in specialized but related technologies, infrastructure, and human resources, which leads to the mass emergence of new hotel and restaurant enterprises. Clusters are the cause of investment; their formation increases the international competitiveness of the country as a whole. Thus, based on the results of calculations of indicators-signs of functioning of enterprises of hotel and restaurant complexes for 2016-2019 and thanks to the Cluster Analysis module, a hierarchical dendrogram of association of enterprises of hotel and restaurant complexes was obtained according to integrated indicators of effective functioning in intersectoral industry of hospitality and innovative services (Figure 12).

Euclidean distances between clusters of enterprises of hotel and restaurant complexes are given in Table 3. The calculation of the Euclidean distance between clusters is calculated by formula (Eq. 19) (Hrosul and Kalienik, 2017):

$$
d_{i j}=\left(\sum_{k=1}^{n}\left(x_{i k}-x_{j k}\right)^{p}\right)^{\frac{1}{p}}
$$

where: $p$-Euclid's metric $(p=2) ; x_{k i}$-the value of the $k$-th feature in the $i$-th object.

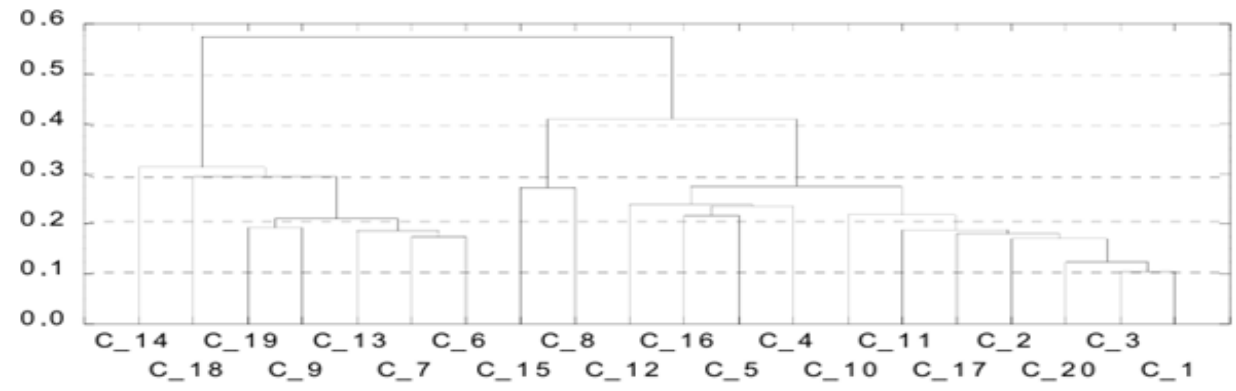

Figure 12. Hierarchical dendrogram of the association of enterprises of hotel and restaurant complexes of Ukraine on the integrated indicators of effective functioning in the intersectoral industry of hospitality and innovative services (Source: authors own calculation s)

Table 3. Matrix of Euclidean distances between clusters of enterprises of hotel and restaurant complexes of Ukraine (Source: authors own calculations)

\begin{tabular}{|c|c|c|c|c|c|c|c|c|c|c|c|c|c|c|c|c|c|c|c|c|}
\hline 10 & $\mathrm{C} 1$ & $\mathrm{C} 2$ & C3 & C4 & $\mathrm{C} 5$ & C6 & C7 & C8 & C9 & $\mathrm{C} 10$ & $\mathrm{C} 11$ & $\mathrm{C} 12$ & C13 & C14 & C15 & C16 & C17 & $\mathrm{C} 18$ & C19 & C20 \\
\hline $\mathrm{C} 1$ & 0.00 & 0.23 & 0.10 & 0.52 & 0.55 & 1.57 & 1.59 & 0.81 & 1.39 & 0.27 & 0.26 & 0.43 & 1.51 & 1.35 & 0.74 & 0.51 & 0.27 & 1.25 & 1.34 & 0.18 \\
\hline $\mathrm{C} 2$ & 23 & 0.00 & 0.17 & 0.44 & 0.49 & 1.49 & 1.51 & 0.74 & 1.34 & 0.29 & 0.21 & 43 & 1.44 & 1.27 & 0.70 & 0.42 & 0.18 & 1.20 & 1.27 & 0.19 \\
\hline $\mathrm{C} 3$ & 10 & 0.17 & 0.00 & 0.48 & .52 & 1.54 & 1.57 & 0.80 & 1.38 & 0.24 & & & 1.49 & 1.34 & & 0.46 & 0.22 & 1.23 & 1.32 & 0.12 \\
\hline $\mathrm{C} 4$ & 52 & .44 & .48 & .00 & .24 & 1.16 & 1.17 & 50 & 1.03 & 0.42 & 0.40 & & 1.13 & 0.99 & & & & & 0.99 & .52 \\
\hline C5 & 55 & 49 & 0.52 & .24 & 0.00 & 1.09 & 1.10 & .44 & 0.93 & 0.47 & 0.48 & 27 & 1.04 & 0.94 & & 0.22 & 0.34 & 0.78 & 0.88 & .56 \\
\hline C6 & 57 & 49 & .54 & 1.16 & 1.06 & 0.00 & 0.17 & 0.80 & 0.37 & 1.51 & 1.46 & 1.18 & 0.19 & 0.41 & 0.5 & 1.15 & 1.37 & 0.46 & 0.35 & .61 \\
\hline C7 & & 51 & 1.57 & .17 & 1.10 & 0.17 & 0.00 & 0.85 & 0.39 & 1.53 & 1.49 & 1.20 & 0.26 & 0.4. & 0. & 1.16 & 1.39 & 0.49 & 0.41 & 1.63 \\
\hline C8 & 81 & 0.74 & 0.80 & 0.50 & 0.44 & 0.80 & 0.85 & 0.00 & 0.66 & 0.78 & 0.75 & 0.47 & 0.74 & 0.57 & 0.27 & 0.50 & 0.65 & 0.59 & 0.58 & 0.86 \\
\hline C9 & 39 & 1.34 & 1.38 & 1.03 & 0.93 & 0.37 & 0.39 & 0.66 & 0.00 & 1.36 & 1.34 & 1.01 & 0.25 & 0.41 & 0.69 & 1.02 & 1.22 & 0.34 & 0.19 & 1.45 \\
\hline $\mathrm{C} 10$ & 27 & 0.29 & 0.24 & 0.42 & 0.47 & 1.51 & 1.53 & 0.78 & 1.36 & 0.00 & 0.22 & 0.42 & 1.47 & 1.32 & 0.76 & 0.44 & 0.26 & 1.21 & 1.31 & 0.24 \\
\hline C11 & 0.26 & 0.21 & 0.19 & 0.40 & 0.48 & 1.46 & 1.49 & 0.75 & 1.34 & 0.22 & 0.00 & 0.39 & 1.43 & 1.27 & 0.74 & 0.39 & 0.22 & 1.17 & 1.28 & 0.23 \\
\hline $\mathrm{C} 12$ & 0.43 & 0.43 & 0.42 & 0.24 & 0.27 & 1.18 & 1.20 & 0.47 & 1.01 & 0.42 & 0.39 & 0.00 & 1.13 & 0.99 & 0.42 & 0.31 & 0.31 & 0.86 & 0.96 & 0.50 \\
\hline $\mathrm{C} 13$ & 51 & 1.44 & 1.49 & 1.13 & 1.04 & 0.19 & 0.26 & 0.74 & 0.25 & 1.47 & 1.43 & 1.13 & 0.00 & 0.35 & 0.83 & 1.12 & 1.33 & 0.40 & 0.21 & 1.56 \\
\hline C14 & 35 & 1.27 & 1.34 & 0.99 & 0.94 & 0.41 & 0.45 & 0.57 & 0.41 & 1.32 & 1.27 & 0.99 & 0.35 & 0.00 & 0.71 & 0.98 & 1.18 & 0.52 & 0.31 & 1.41 \\
\hline $\mathrm{C} 15$ & 74 & 0 & 75 & 15 & 41 & $\overline{0.91}$ & 0.95 & 0.27 & 0.69 & 0.76 & & 42 & 0.83 & 0.7 & 0.00 & 0.51 & 0.61 & 0.62 & 0.65 & 82 \\
\hline$\overline{\mathrm{C} 16}$ & & 0 & 46 & 4 & 2 & 1. & 1.16 & 0.50 & 1.02 & 0.44 & 0.39 & & 1.12 & 0.98 & 0.5 & 0.00 & 0.28 & 0.89 & 0.97 & 0.50 \\
\hline $\mathrm{C} 17$ & & & 22 & & 0.3 & 1.37 & 1.3 & 0.65 & 1.22 & 0.26 & 0.22 & 31 & 1.3 & 1.1 & 0.6 & 0.28 & 0.00 & 1.08 & 1.17 & 0.24 \\
\hline $\mathrm{C} 18$ & & 1.20 & 1.23 & 0.90 & 0.78 & 0.46 & 0.49 & 0.59 & 0.34 & 1.21 & 1.17 & 0.80 & 0.40 & 0.52 & 0.62 & 0.89 & 1.08 & 0.00 & 0.29 & 1.30 \\
\hline$\overline{\mathrm{C} 19}$ & 34 & 1.27 & 1.32 & 0.99 & 0.88 & 0.35 & 0.41 & 0.58 & 0.19 & 1.31 & 1.28 & 0.96 & 0.21 & 0.31 & 0.65 & 0.97 & 1.17 & 0.29 & 0.00 & 1.40 \\
\hline $\mathrm{C} 20$ & 18 & 0.19 & 0.12 & 0.52 & 0.56 & 1.61 & 1.63 & 0.86 & 1.45 & 0.24 & 0.23 & 0.50 & 1.56 & 1.41 & 0.82 & 0.50 & 0.24 & 1.30 & 1.40 & 0.00 \\
\hline
\end{tabular}

The results of construction of the correlation-regression model by clusters of enterprises of hotel and restaurant complexes are given in Table 4. Thus, the calculations show that in the formation of hospitality and innovative services for enterprises of the first cluster in the intersectoral service industry, it is necessary to reduce financial risk (investment), 
conquer new markets (standards, improve service quality, etc.), expand the information base (creation of a base of consumers, suppliers, etc.), rational use of working time (measures to reduce free or unproductive time) (Davydova, 2016; Guaita et al., 2019; Travel, Tourism and Hospitality, 2016). For enterprises of the second cluster, it is necessary to increase their level of development by effective advertising (not only promoting their product but also improving service). Increasing the cost of maintaining management staff will be effective provided effective management decisions that will improve financial state of enterprises of hotel and restaurant complexes in the regions of Ukraine. For the enterprises of the third cluster, it is necessary to increase the level of own development (to introduce international standards to attract additional investments), to introduce innovative measures for market research of competitors (benchmarking, reengineering), to form skilled workers staff who will effectively produce innovative measures for hotel and restaurant business development (use of the system of material and moral motivation to increase innovation and ideology of employees).

Table 4. The results of building a correlation-regression model by clusters of enterprises of the hotel and restaurant complex of Ukraine (Source: authors own calculations)

\begin{tabular}{|c|c|c|c|c|c|}
\hline Regression equation & $\begin{array}{l}\text { Multiple correlation } \\
\text { coefficient }(\mathrm{R})\end{array}$ & $\begin{array}{l}\text { Determination } \\
\text { coefficient }\left(\mathrm{R}^{2}\right)\end{array}$ & $\begin{array}{c}\text { Normalized } \\
\mathrm{R}^{2}\end{array}$ & $\begin{array}{c}\text { Fisher's } \\
\text { criterion F }\end{array}$ & $\begin{array}{c}\begin{array}{c}\text { Approximation } \\
\text { error }\end{array} \\
\end{array}$ \\
\hline \multicolumn{6}{|c|}{ I cluster (7 enterprises of hotel and restaurant complexes - C6; C7; C9; C13; C14; C18; 19$)$ - high level of integrated indicator } \\
\hline $\begin{array}{l}\mathrm{y}_{\mathrm{K}}^{I}=0.3241+0.1511 \times I S 5+0.4812 \times D S 1+ \\
+0.2647 \times 0 S 4+0.3254 \times F S 4+0.4162 \times T S 2\end{array}$ & 0.468 & 0.581 & 0.523 & 10.11 & 0.0134 \\
\hline \multicolumn{6}{|c|}{ II cluster (6 enterprises of hotel and restaurant complexes - C4; C5; C12; C8; C15; C16) - average level of integrated indicator } \\
\hline $\begin{array}{l}\mathrm{y}_{\mathrm{K}}^{I I}=0.4215-0.2515 \times I S 1+0.5164 \times M S 1+ \\
+0.5382 \times P S 4+0.2801 \times Y S 2+0.4382 \times O S 1\end{array}$ & 0.820 & 0.747 & 0.751 & 10.15 & 0.0171 \\
\hline \multicolumn{6}{|c|}{ III cluster (7 enterprises of hotel and restaurant complexes $-\mathrm{C} 1 ; \mathrm{C} 2 ; \mathrm{C} 3 ; \mathrm{C} 10 ; \mathrm{C} 11 ; \mathrm{C} 17 ; \mathrm{C} 20)-$ low level of integrated indicator } \\
\hline $\begin{array}{l}\mathrm{y}_{\mathrm{K}}^{I I I}=0.3843-0.2238 \times I S 2+0.3481 \times M S 2+ \\
+0.5214 \times Y S 4+0.2517 \times 0 S 3+0.1205 \times T S 3\end{array}$ & 0.681 & 0.731 & 0.621 & 11.21 & 0.0173 \\
\hline
\end{tabular}

\section{CONCLUSIONS}

Thus, the introduction of new approaches and methods of the development of hotel and restaurant industry in the intersectoral industry of hospitality and innovative services confirms its existence as a synergetic system that increases the potential of service activities, open new areas of use of its components and indicators, providing synergistic effect when changing the external and internal competitive environment. This will increase the adaptive conditions to forecasted and unforeseen crises in the hospitality industry and innovative services, will balance product quality and customer service, creating a positive image in domestic and foreign markets. The reduction of the influence of external factors to strengthen the competitive advantages of the hotel and restaurant industry can be through the implementation of the following measures: first, hotel and restaurant complexes and other accommodation facilities should improve approaches and mechanisms for attracting customers through the creation of new key competencies, which will positively affect the development of new quality standards and service technologies similar to the standards of the global hotel and restaurant chain.

At the same time, an attractive pricing policy will be an advantage in the competition; secondly, it is more expedient for investors to build a three-star hotel and restaurant complexes for faster return on investment, taking into account one hundred percent occupancy of facilities; thirdly, the hotel and restaurant industry should cooperate more intensively with the state to form joint development and exit from crisis programs, because the crisis motivates the hotel and restaurant business to seek new horizons of cooperation and create unique service technologies (namely, choosing the best employees in the labor market, improving the quality of service, the introduction of new marketing approaches to the development of hospitality and the sale of innovative services, association with other players in the market of hotel and restaurant services, acquisition of assets at favorable prices, i.e., objects in the final stages of implementation). Fourth, the introduction of hotel and restaurant operators will meet the needs of the hotel and restaurant industry in local and regional markets, thus strengthening the key competencies for the successful development of the hospitality industry and innovative services.

\section{REFERENCES}

Andrieieva, V.H., \& Sosnovska, O.A. (2016). Assessment of the current state of investment and innovation activities of enterprises of the real sector of the economy of Ukraine. Problems of the Economy, 1, 68-74. https://doi.org/10. kubg.edu.ua/id/eprint/17419

Arkolakis, C. (2018). Innovation and production in the global economy. American Economic Review, 108(8), 21-28. https://doi.org/ 10.1257/aer.20141743

Barna, M., \& Ruschyshyn, N. (2020). Banking system of the country: elements, functions and potential in ensuring economic growth. Scientific Horizons, 23(10), 54-67. https://doi.org/10.48077/scihor.23(10).2020.54-67

Belhassen, Y. (2020). Metaphors and tourism paradoxes. Tourism Management, 79, 104095. https://doi.org/10.1016/j.tourman.2020.104095

Beliavceva, V. (2018). Innovative character of modernization of managerial information system of the enterprise. International Scientific Journal on Economic Development, 17(3), 42-50. https://doi.org/10.21511/ed.17(3).2018.04

Bobrova, A.V., Stepanov, E.A., \& Tetin, I.A. (2017). Development of methods of optimization of non-tax payments for decrease in expenses of the company at implementation of the foreign economic and resource activity. Optimization of non-tax payments. Journal of Advanced Research in Law and Economics, 8(6), 1711-1726. https://doi.org/10.14505/jarle.v8.6(28).06

Bochulia, T. (2019). Innovative changes in development of enterprise information system: digital transformations, behavioral technologies and new decisions, Consilium Sp. z o.o., Warsaw, 132.

Breuer, H., Fichter, K., Lüdeke-Freund, F., \& Tiemann, I. (2018). Sustainability-oriented business model development: Principles, criteria and tools. International Journal of Entrepreneurial Venturing, 10(2), 256-286. https://doi.org/10.1504/IJEV.2018.092715

Brozovic, D. (2020). Business model based on strong sustainability: Insights from an empirical study. Business Strategy and the Environment, 29(2), 763-778. https://doi.org/10.1002/bse.2440 
Chi, H.K., Huang, K.C., \& Nguyen, H.M. (2020). Elements of destination brand equity and destination familiarity regarding travel intention. Journal of Retailing and Consumer Services, 52, art. no. 101728. https://doi.org/10.1016/j.jretconser.2018.12.012

Chkalova, O., Efremova, M., Lezhnin, V., Polukhina, A., \& Sheresheva, M. (2019). Innovative mechanism for local tourism system management. Entrepreneurship and Sustainability Issues, 6(4), 2052-2067. https://doi.org/10.9770/jesi.2019.6.4(35)

Chorna, M.V., \& Koval, M.S. (2015). Features of management of development of enterprises of restaurant economy. Effective Economy, 1, 1-4. https://doi.org/10.032?op=1\&z=3710

Davydova, O.I. (2016). Cognitive modeling of innovative management of the hotel and restaurant industry. Sustainable development in a socially oriented economy, Striped Printing House, Kharkiv, 195-207.

Dykan, V.L. (2011). Methodical approaches to assessing the competitiveness of the enterprise. Bulletin of Transport Economics and Industry. Economy, 36, 100-105. https://doi.org/10.339.137:334.723

Eyster, J.J., \& DeRoos, J.A. (2009). The Negotiation and administration of hotel and restaurant management contracts, Cornell Hotel and Restaurant Administration Quarterly, 21(2), 5. https://doi.org/10.1177/001088048002100203

Foss, N.J., \& Saebi, T. (2018). Business models and business model innovation: Between wicked and paradigmatic problems. Long Range Planning, 51(1), 9-21. https://doi.org/10.1016/j.lrp.2017.07.006

Guaita, J.M., Martín, J.M., Salinas, J.A., \& Mogorrón-Guerrero, H. (2019). An analysis of the stability of rural tourism as a desired condition for sustainable tourism. Journal of Business Research, 100, 165-174. https://doi.org/10.1016/j.jbusres.2019.03.033

Heimtun, B., \& Lovelock, B. (2017). Communicating paradox: Uncertainty and the northern lights. Tourism Management, 61, 63-69. https://doi.org/10.1016/j.tourman.2017.01.017

Hrosul, V.A., \& Kalienik, K.V. (2017). Modern innovative trends in the formation of a competitive strategy of restaurant enterprises. Innovative Economy, 7-8(70), 72-78. https://doi.org/10.640.432(477)

Khaustova, K.M., Hoblyk, V.V., \& Chernychko, T.V. (2020). Valuation of economic stable development of hospitality enterprises in the region. Scientific Bulletin of Mukachevo State University. Series “Economy”, 1(13), 169-174. https://doi.org/10.31339/2313-8114-2020-1(13)-169-174

Kulman, S. (2020). Digitalization of products - unique offer to attract customers and expand sales market. Scientific Horizons, 7(92), 88-97. https://doi.org/10.33249/2663-2144-2020-92-7-88-97

Kyrnis, N. (2020). Assessment of the competitiveness of catering companies. Scientific Horizons, 23(9), 77-85. https://doi.org/10.48077/ scihor.23(9).2020.77-85

Liang, Z., \& Bao, J. (2020). The growth of urban tourism: With or without limit. Acta Geographica Sinica, 75(8), 1711-1724. https://doi.org/10.11821/dlxb202008011

Liu, C.H., Horng, J.S., Chou, S.F., Huang, Y.C., \& Chang, A. (2018). How to create competitive advantage: the moderate role of organizational learning as a link between shared value, dynamic capability, differential strategy, and social capital. Asia Pacific Journal of Tourism Research, 23(8), 747-764. https://doi.org/10.1080/10941665.2018.1492943

Lupych, O. (2015). Development prospects of the hotel business as part of the eco-agritourism. Scientific Issue of Knowledge, Education, Law and Management, 4(12), 164-168. https://doi.org/10.330:330.3:330.341.424:392.72

Maslii, N., Demianchuk, M., \& Zhadanova, Y. (2020). The mechanism for ensuring the system of balanced consumption and production. Scientific Horizons, 23(9), 57-67. https://doi.org/10.48077/scihor.23(9).2020.57-67

Piatnytska, H.T., \& Naidiuk, V.S. (2017). Modern trends in the restaurant industry in Ukraine. Economy and State, 9, 66-73. https://doi.org/10.005.412:640.43(477)

Postma, A., Buda, D.M., \& Gugerell, K. (2017). The future of city tourism. Journal of Tourism Futures, 3(2), 95-101. https://doi.org/10. 1108/JTF-09-2017-067

Rodríguez, A.J.G., Barón, N.J., \& Martínez, J.M.G. (2020). Validity of dynamic capabilities in the operation based on new sus tainability narratives on nature tourism SMEs and clusters. Sustainability (Switzerland), 12(3), art. no. 1004. https://doi.org/10.3390/su12031004

Rybakova, S.S., \& Myronov, D.A. (2019). Quality and innovation in development management of hotel facilities. Scientific Bulletin of Mukachevo State University. Series “Economy”, 2(12), 73-79. https://doi.org/10.31339/2313-8114-2019-2(12)-73-80

Shevchenko, V.S. (2019). Management leader: personal qualities and their efficiency. Scientific Bulletin of Mukachevo State University. Series “Economy", 1(11), 53-59. https://doi.org/10.31339/2313-8114-2019-1

Shytikova, T.V., \& Ignatyshyn, M.I. (2020). Evaluation of restaurant activity of cities and districts of the Zakarpattia oblast by the hierarchy analysis method. Scientific Bulletin of Mukachevo State University. Series “Economy”, 1(13), 175-183. https://doi.org/10.31339/23138114-2020-1(13)-175-183

Trusova, N.V., Cherniavska, T.A., Pasieka, S.R., Hranovska, V.H., Prystemskyi, O.S., \& Demko, V.S. (2020a). Innovative clustering of the region in the context of increasing competitive positions of the enterprises of the tourist-recreational destination. GeoJournal of Tourism and Geosites, 33(3), 1126-1134. https://doi.org/10.30892/gtg.31326-549

Trusova, N.V., Kyrylov, Y.Y., Hranovska, V.H., Prystemskyi, O.S., \& Sakun, A. Zh. (2020b). The imperatives of the development of the tourist services market in spatial polarization of the regional tourist system. GeoJournal of Tourism and Geosites, 29(2), 565-582. https://doi.org/10.30892/gtg.29215-490

Trusova, N.V., Tanklevska, N.S., Cherniavska, T.A., Prystemskyi, O.S., Yeremenko, D.V., \& Demko, V.S. (2020c). Financial provision of investment activities of the subjects of the world industry of tourist services. Journal of Environmental Management and Tourism, 11, 4(44), 890-902. https://doi.org/10.14505//jemt.v11.4(44).13

Vishnevskaya, E.V., Klimova, T.B., Koroleva, I.S., Slinkova, O.K., \& Yasenok, S.N. (2019). The infrastructure of public catering in the context of tourist city space development. Humanities and Social Sciences Reviews, 7(5), 975-981. https://doi.org/10.18510/hssr.2019.75128

Vlasenko, O., \& Budnik, O. (2020). The digital transformation of marketing technologies: cooperative vector. Scientific Horizons, 6(91), 4251. https://doi.org/10.33249/2663-2144-2020-91-6-42-51

Yatsun, L.M. (2018). Culinary diversity and marketing innovations in international tourism. Ivanchenko I. Publishing House, Kharkiv, 89-96.

*** Collection "Ukraine-2018" (2019). Retrieved from https://ukrstat.org/uk/druk/publicat/kat_u/2019/zb/07/Ukr_cifra_2018_u.pdf.

*** Statistical publication of the Regions of Ukraine. (2018). http://www.ukrstat.gov.ua/druk/publicat/kat_u/2018/zb/11/zb_ru1ch2018.pdf.

*** Travel, Tourism and Hospitality. (2016). Retrieved from https://www.statista.com/markets/420/travel-tourism-hospitality 